\title{
Microbiological profile of asymptomatic bacteriuria in pregnancy
}

\author{
Anu Mary Bose*, Sreekumary P. K., Sobha Kurian Pulikkottil
}

Department of Microbiology, Government Medical College, Kottayam, Kerala, India

Received: 05 January 2017

Revised: 09 January 2017

Accepted: 23 February 2017

\author{
*Correspondence: \\ Dr. Anu Mary Bose, \\ E-mail: doc_anubose@yahoo.co.in
}

Copyright: () the author(s), publisher and licensee Medip Academy. This is an open-access article distributed under the terms of the Creative Commons Attribution Non-Commercial License, which permits unrestricted non-commercial use, distribution, and reproduction in any medium, provided the original work is properly cited.

\begin{abstract}
Background: Asymptomatic bacteriuria is the presence of actively multiplying bacteria within the urinary tract in the absence of any symptoms. Anatomical and physiological changes make women more susceptible to UTI in pregnancy. The objective of present study was to determine the percentage of pregnant women with asymptomatic bacteriuria and its microbiological profile.

Methods: A total of 555 antenatal women who had no clinical features of urinary tract infection were recruited for this study over a period of one year. Clean catch mid-stream urine sample was collected and semi quantitatively cultured immediately. Significant bacteriuria was identified and antibiotic sensitivity found out by conventional methods.

Results: Significant growth was observed in 26 samples. There was no association between age, parity, gravidity, period of gestation and asymptomatic bacteriuria. Gram stain was found to be the best screening test. Escherichia coli were the commonest organism isolated. Escherichia coli and Staphylococcus saprophyticus were the most resistant organisms.

Conclusions: Escherichia coli, the most common organism isolated, was resistant to most of the commonly used antibiotics. Wet film examination, the most commonly used screening test in our set up, was less sensitive and specific. So culture has to be done in all antenatal cases for screening asymptomatic bacteriuria of pregnancy.
\end{abstract}

Keywords: Asymptomatic bacteriuria in pregnancy, Pregnancy, Screening tests, Semi-quantitative culture, UTI

\section{INTRODUCTION}

Urinary tract infections are amongst the most common infections encountered in clinical practise. About $50 \%$ of women experience at least one episode of urinary tract infection during their life time. ${ }^{1}$ UTI in pregnancy can be symptomatic or asymptomatic. ${ }^{1-4}$ Asymptomatic bacteriuria (ASB) is defined as persistently and actively multiplying bacteria in significant numbers i.e., $10^{5}$ bacteria per $\mathrm{ml}$ within the urinary tract without any obvious symptoms. ${ }^{1-5}$ It is also known as Covert bacteriuria. Females are more susceptible for these infections because of the short length of urethra along with proximity to warm, moist anal canal. ${ }^{4}$ Sexual intercourse facilitate the ascent of bacteria into bladder. The pregnant females are two times more commonly affected than age matched non-pregnant females. The reason behind this is urinary stasis due to progesterone effect in pregnancy in addition to different anatomical changes occurring during pregnancy. ${ }^{2,4}$ Various studies from the west have documented the prevalence of asymptomatic bacteriuria in pregnancy to be between 2 and $7 \%$ while in India it was found to be on higher side i.e., between 5 and $17 \% .^{6-10}$ Studies in African region showed higher prevalence than both these regions. ${ }^{11}$ Commonest organisms responsible are Escherichia coli $(80-85 \%)$, followed by coagulase negative 
Staphylococcus species, Klebsiella species, Pseudomonas species, and Proteus species. ${ }^{6-11}$

The Gold standard investigation for detection of asymptomatic bacteriuria is urine culture. ${ }^{1-3}$ Therefore, urine culture at first prenatal visit or between 12 and 16 weeks of gestation should be considered as a screening test of choice. ${ }^{1,2}$ Detection of asymptomatic bacteriuria during pregnancy is important as subsequently it may lead to symptomatic infection during that pregnancy in $25 \%$ of infected women, chronic infection resistant to chemotherapy, pyelonephritis, low birth weight (LBW) babies and preterm delivery. ${ }^{9}$ This study is designed to determine the bacterial profile and antibiotic susceptibility pattern of uropathogen among pregnant women, along with the outcome of urinary tract infection in pregnancy.

The objective of present study was to find out the percentage of women with asymptomatic bacteriuria in pregnancy, coming to Obstetrics OPD in Government Medical College, Kottayam, Kerala, India and to find out the common isolates and their antibiotic sensitivity pattern.

\section{METHODS}

It is a descriptive study carried out at Department of Microbiology, Government Medical College, Kottayam and Department of Obstetrics and Gynaecology, Government Medical College, Kottayam, Kerala, India. The study was carried out for one year from February 2014. Study population includes antenatal women who attended Obstetrics OPD during 12-16 weeks of pregnancy or for first time during whole pregnancy.

\section{Inclusion criteria}

Asymptomatic pregnant females who were willing to participate in study.

\section{Exclusion criteria}

Those with signs and symptoms of UTI, those with diabetes, those with any structural anomalies of urinary tract, those patients who took antibiotics in past one week and those who were not willing to participate were excluded from this study.

Sample size was 550 and it is the minimum sample size as calculated with the formulae $4 \mathrm{pq} / \mathrm{d}^{2}$ using prevalence (p) $=15, d=20 \%$ of p. Sampling methodology was nonprobability convenient sampling.

\section{Sample collection and processing}

The study was conducted after obtaining necessary permission from institutional ethics committee, over a period of one year from February 2014, on a total of 555 asymptomatic pregnant females at their first visit in whole pregnancy or during 12-16 weeks of pregnancy. ${ }^{1,2}$ Informed consent was taken. The pregnant females were instructed how to collect clean catch mid-stream urine sample. The samples were taken in sterile leak proof universal containers and immediately transferred and processed within 2 hours of collection.

Samples were subjected to macroscopic examination, wet film examination for pyuria, Gram stain, catalase test, nitrate reductase (Griess) test and semi quantitative culture method. The semi quantitative culture was done by surface streaking method on 5\% sheep Blood agar, Cysteine Lactose Electrolyte Deficient agar with bromothymol blue and MacConkey agar. HiCrome UTI agar and HiCrome Strep B Selective Agar (both by Hi Media Laboratories, Mumbai) was also used to aid in early identification of isolates with significant bacteriuria. For the inoculation, sterile standard nichrome wire loop, with volume holding capacity of $0.001 \mathrm{ml}$ was used. The plates were incubated at $37^{\circ} \mathrm{C}$ for 24 hours.

HiCrome UTI agar media was prepared as per manufacturer's instructions. Sample was inoculated and incubated at $37^{\circ} \mathrm{C}$ overnight. Differentiation is aided by different colour of different bacteria like E. coli $\rightarrow$ dark pink to reddish, Proteus $\rightarrow$ brown halo, Klebsiella, Enterobacter and Serratia $\rightarrow$ metallic blue, S. aureus $\rightarrow$ golden, opaque, small, Citrobacter $\rightarrow$ metallic blue with red halo, S. saprophyticus $\rightarrow$ pink, opaque, small, Candida albicans $\rightarrow$ colourless, Streptococcus agalactiae $\rightarrow$ light blue, Pseudomonas aeruginosa $\rightarrow$ Translucent, cream to blue.

HiCrome Strep B selective agar media was prepared according to manufacturer's instructions. Blue coloured colonies with luxuriant growth of Streptococcus agalactiae was observed after incubation at $37^{\circ} \mathrm{C}$ overnight.

\section{Screening tests done}

\section{Wet film examination of uncentrifuged urine for pyuria}

A $0.05 \mathrm{ml}(50 \mu \mathrm{l})$ of uncentrifuged well mixed urine sample was transferred carefully on to the middle of a microscope slide. A coverslip, 22 X $22 \mathrm{~mm}$ was applied immediately avoiding trapped bubbles so that the film should show a small excess of fluid along the edges of the coverslip. The prepared film was examined under microscope in high power field. The finding of more than 1 leukocyte per 7 high power fields corresponds with more than $10^{4}$ leukocytes per ml-which was considered as significant pyuria. ${ }^{12,13}$

Gram stain of well mixed uncentrifuged urine for microorganisms

A drop of well mixed urine is allowed to air dry, the smear is fixed, stained and examined under oil immersion $(1000 \mathrm{X}){ }^{3}$ The presence of at least one bacterium per oil 
immersion field in a midstream, clean-catch, Gramstained, uncentrifuged urine correlates with $10^{5}$ bacteria per ml of urine or more. Smear is discarded as negative after examining at least 20 oil immersion fields. ${ }^{4,9}$

\section{Urinary nitrite detection}

The Griess reagent was prepared by dissolving $1.5 \mathrm{gm}$ of sulphanillic acid in $450 \mathrm{ml}$ of $10 \%$ acetic acid. This was then added to a solution of 0.6 gm of $\propto$ - naphthylamine dissolved in $60 \mathrm{ml}$ of boiling distilled water. The reagent remains stable for several months when stored in a stopper amber bottle and refrigerated. Deterioration of the test reagent is detected by the development of a pink color. If pink color develops; reagent can be regenerated by shaking it vigorously with small amounts of metallic zinc powder and filtering it.

Urine is tested by adding $1.0 \mathrm{ml}$ of urine to $1.0 \mathrm{ml}$ of the reagent in a clean test tube. The immediate development of a pink color to dark red color indicates the presence of nitrites in urine and is called a positive reaction. The $\propto$ naphthylamine was handled carefully because of its possible hazards. ${ }^{14}$

Urinary catalase detection in uncentrifuged well mixed urine sample

1.5 to $2 \mathrm{ml}$ of urine was placed in a test tube. Four drops of $10 \%$ hydrogen peroxide was added to the test tube, and the mixture was shaken gently for 5 seconds. A positive finding was defined as the formation of effervescence sufficient to form a complete ring or layer on the surface of the liquid within 1 to 2 minutes of the addition of the hydrogen peroxide. The test result was considered negative in the absence of effervescence or when the ring of effervescence was incomplete after two minutes. ${ }^{9,15}$

\section{Accuracy of screening tests}

All the screening tests were evaluated for its accuracy as screening tests by calculating sensitivity, specificity, positive predictive value and negative predictive value. ${ }^{16}$

\section{Definitions and formulae}

- $\quad$ True positive (TP): Screening test and culture, both positive

- $\quad$ False positive (FP): Positive screening test finding and negative culture

- True negative (TN): Screening test and culture, both negative

- False negative (FN): Screening test negative and culture positive

- $\quad$ Sensitivity $=\mathrm{TP} /(\mathrm{TP}+\mathrm{FN})$ : Probability that screening test will be positive in patients with UTIs (positive culture)

- Specificity = TN/(TN+FP): Probability that screening test will be negative in patients without UTIs (negative culture)
- Positive predictive value (PPV): $\mathrm{TP} /(\mathrm{TP}+\mathrm{FP})$ : Probability that a UTI is present when screening test is positive.

- Negative predictive value (NPV): $\mathrm{TN} /(\mathrm{TN}+\mathrm{FN})$ : Probability that a UTI is not present when screening test is negative

\section{Semi quantitative culture of urine}

After mixing thoroughly, the top of the container was removed. The calibrated loop was introduced vertically into the urine and taken out. Loop was touched to the centre of the plate, from which the inoculum was spread in a line across the plate. Without flaming or re-entering urine, loop was drawn across the entire plate, crossing the first inoculum streak numerous times to produce isolated colonies. Plates were incubated at $37^{\circ} \mathrm{C}$ for 24 hours. Number of colonies were counted and multiplied by 1000 to get the colony count. ${ }^{3}$

\section{Interpretation}

- No bacteriuria - If no growth was present.

- No significant bacteriuria - If the colony count was $<10^{5}$ colony-forming units $/ \mathrm{ml}$.

- $\quad$ Significant bacteriuria - If colony count was $>10^{5}$ colony-forming units/ml of a particular organism except in case of growth of gram-positive cocci where even $10^{2}$ cfus per $\mathrm{ml}$ were taken as significant.

\section{Antibiotic sensitivity testing of bacterial isolates}

Antibiotic sensitivity testing was done using KirbyBauer method (disc diffusion), with 0.5 McFarland standard turbidity of the inoculum on blood agar for Streptococcus species. and Mueller-Hinton agar for other isolates. Standardization of antibiotic susceptibility testing was done by using standard strans of Escherichia coli - ATCC 25922, Enterococcus faecalis - ATCC 29212 and Staphylococcus aureus - ATCC 25923 as control strains. E-test, Vitek 2 systems and agar dilution was done to detect the MIC of Vancomycin for all Staphylococcus species. Antibiotics were tested and zone of inhibition of growth was measured and interpreted according to CLSI guidelines. ${ }^{17}$

All antibiotics were not reported. Only antibiotics which can be safely given in pregnancy and those which attain good urinary concentration were reported. Antibiotics which can be given orally were preferred for reporting. Antibiotics used were Ampicillin, Amoxicillinclavulanic acid, Cephalosporin 1st generation(Cephalexin), Cephalosporin 3rd generation (Cefotaxime), Cotrimoxazole (Trimethoprim / Sulphamethoxazole), Nitrofurantoin, Norfloxacin and Ciprofloxacin depending upon the isolates. ${ }^{18}$

Test for ESBL production was also done for relevant isolates. The data was numerically coded and was entered in Microsoft excel spread sheet. Further analysis was 
done using the software SPSS 16 and tables and charts were created using excel. The level of statistical significance was noted if $\mathrm{p}$ value was $<0.05$ and high significance was $\mathrm{p}<0.01$.

\section{RESULTS}

As per the inclusion and exclusion criteria, mid-stream clean catch urine sample was collected from 555 asymptomatic pregnant females. Out of the total 555 subjects, $26(4.68 \%)$ were having asymptomatic bacteriuria of pregnancy (Figure 1).

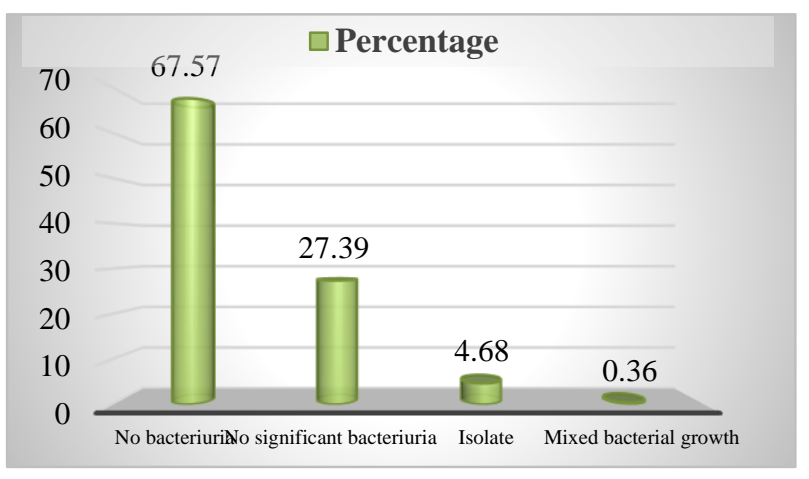

Figure 1: Report of all the samples studied.

Most common age group affected was 26-30 years followed by 21-25 years and 31-35 years (Figure 2).

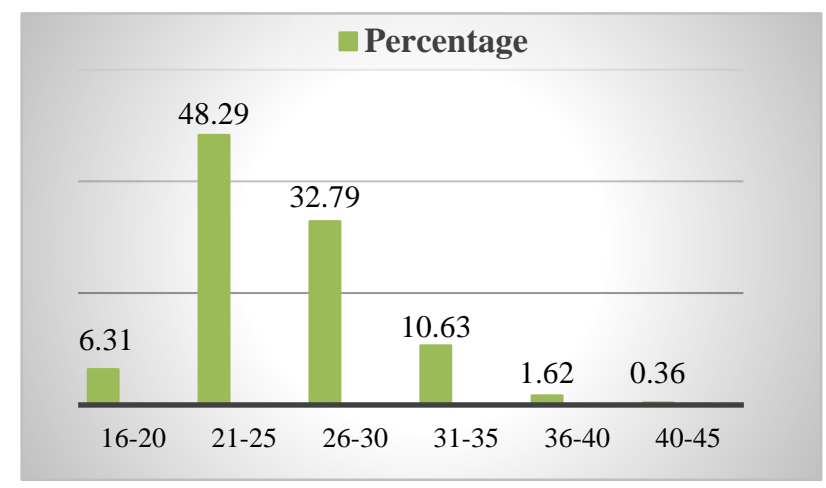

Figure 2: Age distribution.

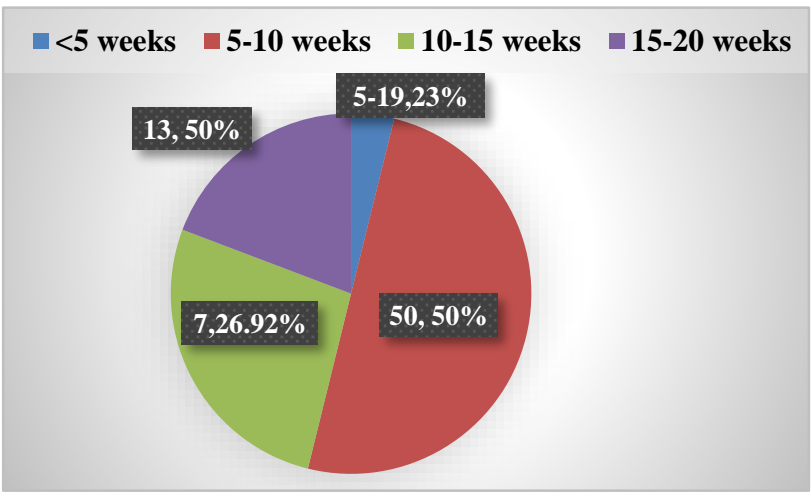

Figure 3: Period of gestation wise distribution of those with ASB.
ASB was more common among primi gravida (53.85\%) followed by gravida $2(30.77 \%)$. Parity wise distribution of ASB was as follows: nulli para (57.69\%) >para1 $(30.77 \%)>$ para $2(7.69 \%)>$ para3 $(3.85 \%)$. Maximum case of ASB was reported during 5-10 weeks (50\%) followed by 7 weeks (26.92\%) (Figure 3 ).

Out of the 26 cases with asymptomatic bacteriuria of pregnancy, $23(88.46 \%)$ were not having any risk factors. Only $2(7.69 \%)$ cases had associated UTI (before pregnancy or during previous pregnancy) and one $(3.85 \%)$ had UTI in early period of present pregnancy. So overall a $10 \%$ of subjects were having history of UTI.

Sensitivity, specificity, positive predictive value and negative predictive value of the screening tests are shown in Table 1.

Table 1: Sensitivity, Specificity, Positive predictive and negative predictive value of screening tests.

\begin{tabular}{|lllll|}
\hline & $\begin{array}{l}\text { Wet } \\
\text { film for } \\
\text { pyuria }\end{array}$ & $\begin{array}{l}\text { Gram } \\
\text { stain }\end{array}$ & $\begin{array}{l}\text { Urinary } \\
\text { catalase }\end{array}$ & $\begin{array}{l}\text { Urinary } \\
\text { nitrite }\end{array}$ \\
\hline $\begin{array}{l}\text { True } \\
\text { positives }\end{array}$ & 173 & 168 & 144 & 13 \\
\hline $\begin{array}{l}\text { False } \\
\text { negative }\end{array}$ & 07 & 10 & 36 & 167 \\
\hline $\begin{array}{l}\text { True } \\
\text { negative }\end{array}$ & 268 & 374 & 375 & 375 \\
\hline $\begin{array}{l}\text { False } \\
\text { positive }\end{array}$ & 107 & 01 & 0 & 0 \\
\hline $\begin{array}{l}\text { Sensitivity } \\
\text { Specificity }\end{array}$ & $71.4 \%$ & $99.73 \%$ & $100 \%$ & $100 \%$ \\
\hline $\begin{array}{l}\text { Positive } \\
\text { predictive } \\
\text { value }\end{array}$ & $60.2 \%$ & $99.4 \%$ & $100 \%$ & $100 \%$ \\
\hline $\begin{array}{l}\text { Negative } \\
\text { predictive } \\
\text { value }\end{array}$ & $97.4 \%$ & $99.7 \%$ & $93.5 \%$ & $84.8 \%$ \\
\hline
\end{tabular}

Table 2: Microbiological profile of asymptomatic bacteriuria.

\begin{tabular}{|lll|}
\hline Isolate & No & $\%$ \\
\hline E. coli & 07 & 26.92 \\
\hline K. pneumoniae & 06 & 23.08 \\
\hline Citrobacter koseri & 02 & 7.69 \\
\hline Staphylococcus aureus & 02 & 7.69 \\
\hline $\begin{array}{l}\text { Methicillin resistant coagulase negative } \\
\text { Staphylococci (MRCoNS) }\end{array}$ & 03 & 11.54 \\
\hline Enterococcus faecalis & 02 & 7.69 \\
\hline Candida tropicalis & 01 & 3.85 \\
\hline Streptococcus agalactiae & 03 & 11.54 \\
\hline Total & $\mathbf{2 6}$ & $\mathbf{1 0 0 . 0 0}$ \\
\hline
\end{tabular}

Out of the 26 samples which were having ASB, 15 $(57.7 \%)$ were gram negative bacteria, 10 (38.5\%) were gram positive bacteria and one $(3.8 \%)$ was yeast. Most 
common isolate was Escherichia coli followed by $K$. pneumoniae, Staphylococcus saprophyticus, Streptococcus agalactiae, Citrobacter koseri,
Staphylococcus aureus, Enterococcus faecalis and Candida tropicalis respectively (Table 2).

Table 3: Sensitivity of gram positive isolates.

\begin{tabular}{|lllll|}
\hline Drugs tested & $\begin{array}{l}\text { Staphylococcus } \\
\text { aureus }\end{array}$ & $\begin{array}{l}\text { Methicillin resistant coagulase } \\
\text { negative Staphylococci }\end{array}$ & $\begin{array}{l}\text { Enterococcus } \\
\text { faecalis }\end{array}$ & $\begin{array}{l}\text { Streptococcus } \\
\text { agalactiae }\end{array}$ \\
\hline Ampicillin & $0(0 \%)$ & $0(0 \%)$ & $2(20 \%)$ & $3(30 \%)$ \\
\hline Gentamicin & $1(10 \%)$ & $1(10 \%)$ & $0(0 \%)$ & $0(0 \%)$ \\
\hline Erythromycin & $1-\mathrm{NR}(10 \%)$ & $0-\mathrm{NR}(0 \%)$ & 2 -NR $(20 \%)$ & $3-\mathrm{NR}(30 \%)$ \\
\hline Cephalexin & $2(20 \%)$ & $0(0 \%)$ & $0-\mathrm{NR}(0 \%)$ & $3(30 \%)$ \\
\hline Amikacin & $2(20 \%)$ & $3(30 \%)$ & $0(0 \%)$ & $0(0 \%)$ \\
\hline Vancomycin & $2(20 \%)$ & $3(30 \%)$ & $2(20 \%)$ & $3(30 \%)$ \\
\hline Cloxacillin & $2(20 \%)$ & $0(0 \%)$ & $\mathrm{NT}$ & $\mathrm{NT}$ \\
\hline Mox-Clav & $1(10 \%)$ & $0(0 \%)$ & $2(20 \%)$ & $2(20 \%)$ \\
\hline Linezolid & 2 -NR $(20 \%)$ & $3-\mathrm{NR}(30 \%)$ & 2 -NR $(20 \%)$ & 2 -NR $(20 \%)$ \\
\hline
\end{tabular}

NR- Not reported, NT- Not tested

Table 4: Sensitivity of gram negative isolates.

\begin{tabular}{|llll|}
\hline Drugs & Escherichia coli & Klebsiella preumoniae & Citrobacter koseri \\
\hline Ampicillin & $1(6.25 \%)$ & 0 & 0 \\
\hline Gentamicin & $6(37.5 \%)$ & $6(37.5 \%)$ & $2(12.5 \%)$ \\
\hline Cephalexin & $3(18.75 \%)$ & $5(31.25 \%)$ & 0 \\
\hline Amikacin & $6(37.5 \%)$ & $6(37.5 \%)$ & $2(12.5 \%)$ \\
\hline Cefotaxime & $5(31.25 \%)$ & $6(37.5 \%)$ & $2(12.5 \%)$ \\
\hline Cotrimoxazole & $3(18.75 \%)$ & $5(31.25 \%)$ & $2(12.5 \%)$ \\
\hline Ciprofloxacin & $4(25 \%)$ & $6(37.5 \%)$ & $2(12.5 \%)$ \\
\hline Cefoperazone-sulbactum & $7(43.75 \%)$ & $6(37.5 \%)$ & $2(12.5 \%)$ \\
\hline Piperacillin- tazobactum & $7(43.75 \%)$ & $6(37.5 \%)$ & $2(12.5 \%)$ \\
\hline Meropenem & $7(43.75 \%)$ & $6(37.5 \%)$ & $2(12.5 \%)$ \\
\hline Norfloxacin & $4(25 \%)$ & $5(31.25 \%)$ & $2(12.5 \%)$ \\
\hline Nitrofurantoin & $5(31.25 \%)$ & $3(18.75 \%)$ & 0 \\
\hline Imipenem & $7(43.75 \%)$ & $6(37.5 \%)$ & $2(12.5 \%)$ \\
\hline Mox-Clav & $3(18.75 \%)$ & $5(31.25 \%)$ & 0 \\
\hline
\end{tabular}

Antibiotic sensitivity of the isolates is shown in Table 3 and Table 4. Complications detected due to asymptomatic bacteriuria are shown in Table 5 .

Table 5: Complications of asymptomatic bacteriuria detected on follow up.

\begin{tabular}{|lll|}
\hline Complications & No. & $\%$ \\
\hline No complications & 14 & $53.80 \%$ \\
\hline Recurrent ASB & 623 & $0.08 \%$ \\
\hline $\begin{array}{l}\text { Symptomatic bacteriuria (except } \\
\text { pyelonephritis) }\end{array}$ & 5 & $19.2 \%$ \\
\hline Pre- term labour & 1 & $3.84 \%$ \\
\hline Total & $\mathbf{2 6}$ & $\mathbf{1 0 0}$ \\
\hline
\end{tabular}

\section{DISCUSSION}

A one year study was conducted on microbiological profile of asymptomatic bacteriuria in pregnancy,
Government Medical College, Kottayam. A total of 555 samples were studied. Significant bacteriuria was noted in $26(4.68 \%)$ of isolates.152 $(27.39 \%)$ showed no significant bacteriuria and in $375(67.57 \%)$, there was no growth. The low percentage of asymptomatic bacteriuria may be attributed to the good ante natal care hygiene and awareness among people of Kerala.

The prevalence of asymptomatic bacteriuria in the following studies were similar to our study- Lata $\mathrm{R}$ Chandel et alfrom Shimla (7.34\%) and J Jayalakshmi et al from Bangalore (7.4\%). ${ }^{8,19}$ Maximum pregnant females with asymptomatic bacteriuria was noted in age group 26-30 years $(30.77 \%)$ followed by $21-25$ years and $31-35$ years (both $26.92 \%$ ). The $\mathrm{p}$ value of association between age group and asymptomatic bacteriuria of pregnancy was $0.15>0.05$. So, the association was not statistically significant. Similar results were obtained in study conducted by Ananthi Kasinathan et al from Pondicherry in 2014, with maximum subjects with ASB in the age 
group of 26-30 years. ${ }^{20}$ Many studies show advancing age as a risk factor for acquiring ASB in pregnancy because there is decrease in glycogen deposition and reduction in the lactobacillus as a part of ageing process which enhances bacterial adherence and invasion by pathogens and make them more susceptible. ${ }^{21}$

Of the total 555 samples, 293 (52.8\%) was primi gravda. Asymptomatic bacteriuria in pregnancy was more common among primigravida (53.85\%) compared to multigravida. This association was also not found to be statistically significant $(\mathrm{p}=0.115>0.05$ ). The findings were correlating with the findings of Sudha Kerure et al from Karnataka in 2012. ${ }^{22}$ Out of the total 555 samples, $335(60.36 \%)$ were nullipara, $167(30.09 \%)$ were para-1 and rest $10 \%$ were para- 2 and para- 3 . In samples with asymptomatic bacteriuria in pregnancy (26 samples), 15 $(57.69 \%)$ were from nulliparous women and $8(30.77 \%)$ were para-1. A study by Lavanya and Jogalakshmi from India also gave similar results. ${ }^{9}$ As $p$ value of association between parity and significant bacteriuria was more than 0.05 (0.11), this association was also not found to be statistically significant.

Out of the 555 samples, $263(47.39 \%)$ were in 5-10 weeks of gestation and $230(41.44 \%)$ were in $15-20$ weeks of gestation. Maximum number of asymptomatic bacteriuria was detected in 5-10 weeks of gestation $(50 \%)$ followed by $10-15$ weeks $(26.92 \%)$ and $15-20$ weeks (19.23\%). This association was also not found to be statistically significant ( $p$ value $=0.465>0.05$ ) this study was correlating with a study conducted by Lata R. Chandel et al from Shimla in. ${ }^{19}$

Age, parity and gestational age were not associated with UTI, like in this study, according to a study conducted by Hamdan et al in. ${ }^{23}$ According to Paul Erhunmwunse Imade et al from Nigeria there was no significant difference in the prevalence of asymptomatic bacteriuria with respect to trimester. ${ }^{6}$

Out of the 26 cases with asymptomatic bacteriuria of pregnancy, $23(88.46 \%)$ were not having any risk factors. Only $2(7.69 \%)$ cases had associated UTI before pregnancy or during previous pregnancy and 1 (3.85\%) had UTI in early period of present pregnancy. So overall $10 \%$ of subjects were having history of UTI. According to a study by Agersew Alemu et al from Ethiopia, thirteen $(3.4 \%)$ and $47(12.2 \%)$ of study subjects had history of previous catheterization and urinary tract infection, respectively. ${ }^{24}$ Of all considered variables only history of catheterization and previous history of UTI were significantly associated with UTI. There was no association between maternal age, parity, gravidity, trimester, occupation, marital status and education with bacteriuria.

\section{Accuracy of screening tests}

According to this study Gram stain was the most sensitive test, i.e. there is high probability that gram stain will be positive in those with asymptomatic bacteriuria of pregnancy. Urinary catalase, urinary nitrite and Gram stain were highly specific according to this study. That means there is high probability that urinary catalase, nitrite and Gram stain will be negative in subjects without asymptomatic bacteriuria of pregnancy. Urinary catalase, urinary nitrite and Gram stain were also having a high positive predictive value which means in a subject with asymptomatic bacteriuria of pregnancy there is high chance that these tests will be positive. Gram stain was having the highest negative predictive value followed by wet film for pyuria which means in a subject without asymptomatic bacteriuria of pregnancy there is high chance that these tests will be negative. Gram stain examination was having similar sensitivity (96.0\%), specificity (99.2\%), positive predictive value $(97.6 \%)$ and negative predictive value $(98.7 \%)$ according to a study conducted by Celso Lui'Z Cardoso et al from Brazil. ${ }^{25}$

As there was no consensus in the methods used for wet film examination and the criteria for significant pyuria, different studies showed different values on analysis as a screening test. A study conducted by Taneja et al showed sensitivity, specificity, positive predictive value and negative predictive value of wet film examination for pyuria to be $68.4 \%, 60.8 \%, 32.7 \%$ and $87.3 \%$ respectively. ${ }^{26}$ Another study conducted by Willy Fred Nabbugodi et al sensitivity $(67.5 \%)$, specificity $(88.2 \%)$, positive predictive value $(67.5 \%)$ and negative predictive value $(88.2 \%){ }^{27}$ These two studies were similar to our study on wet film examination. According to Morike Ngobe Mokube et al from Cameroon, sensitivity, specificity, positive predictive value and negative predictive value of urinary (Griess) nitrite test were respectively $8 \%, 98.7 \%, 67 \%$ and $77.8 \% .^{28}$ The lower sensitivity of nitrite tests compared to previous reports may be due to the fact that this test is more accurate when the first voided specimen is collected or when urine has been stored in bladder for over four hours. It was difficult to ensure such conditions in our study. The presence of abnormal amounts of urobilinogen and ascorbic acid in urine as well as a urinary $\mathrm{pH}$ of $<6$ and bacteriuria due to gram-positive cocci or nonfermentative bacilli, such as Pseudomonas species. account for some of the falsenegative results. ${ }^{29,30}$ False negatives can also occur when the organism present does not produce nitrate reductase and when dietary nitrate is absent. ${ }^{28}$ Catalase test was having similar sensitivity $(83 \%)$ in a study conducted by Stephen A. Berger et al from Israel and Shilpa et al from Bangalore, India. ${ }^{30}$ Many organisms causing urinary tract infection contain the enzyme catalase. ${ }^{31}$ The presence of catalase may be due to bacteria, but also to erythrocytes, WBC, or kidney cells. Therefore, this test is not specific for bacteria. ${ }^{32}$ But in this study no false positivity was recorded for catalase reaction. This may be because of decreased number of WBC's and reduced immune 
response in asymptomatic bacteriuria of pregnancy. Catalase can also be false negative for catalase negative organisms and yeasts which were present in our study.

\section{Microbiological profile of asymptomatic bacteriuria in pregnancy}

Out of the 26 samples with significant growth, 15 were Gram negative bacteria (57.7\%), 10 were Gram positive bacteria (38.5\%) and 1 was fungi (3.80\%). Escherichia coli was the most common organism isolated (57.7\%), followed by Klebsiella pneumoniae sub species. pneumoniae (23.08\%), Staphylococcus saprophyticus and Streptococcus agalactiae (both 11.54\%), Citrobacter koseri, Staphylococcus aureus and Enterococcus faecalis (all three $7.69 \%$ ) and Candida tropicalis (3.85\%). Most studies report Escherichia coli as the most common organism isolated followed by Klebsiella species. According to a study conducted by Gayathree et al from Hassan, Karnataka, Escherichia coli emerged as the most frequent cause of ASB with 32 cases $(51.61 \%)$, followed by Proteus mirabilis with 9 cases (14.51\%), Staphylococcus aureus and Klebsiella pneumonia with 6 cases $(9.67 \%)$ each, Acinetobacter species., with 5 cases (8.05\%), Pseudomonas aeruginosa with 3 cases (4.83\%) and Enterococcus faecalis with 1 case $(1.61 \%) .{ }^{33}$

According to another study conducted by Kheya Mukherjee et al from West Bengal, Gram negative organisms were predominant $(80.95 \%)$ causative agents than Gram positive organisms (19.05\%) and E. coli $(57.14 \%)$ was the most common organism isolated. ${ }^{34}$ According to a study by Madhu Udawat et al in India, there was an increasing trend in the prevalence of $S$. aureus infection (15.28\%). ${ }^{35}$ This dramatic increase in prevalence rate can be attributed to the emergence and global spread of Staphylococcus aureus. Hence, recognizing this change in the spectrum of uropathogens remains important to guide changes in empirical antimicrobial therapy. According to Nithyasree et al from Tamilnadu, majority of isolates were Gram negative bacteria (81.39\%). ${ }^{36}$ Gram-positive organisms were responsible only for $18.6 \%$. E. coli $(65.11 \%)$ was the most prevalent uropathogen isolated followed by Klebsiella pneumonia and Staphylococcus aureus, accounted $11.62 \%$ for each. The least prevalent bacteria isolated were Proteus mirabilis (4.65\%).

\section{Antibiotic sensitivity pattern}

\section{Gram positive isolates}

Staphylococcus aureus isolates was $100 \%$ sensitive to Cephalosporin $1^{\text {st }}$ generation drugs (Cephalexin). None of the Staphylococcus species was sensitive to Ampicillin and Nitrofurantoin. $50 \%$ of Staphylococcus aureus strains were sensitive to Amoxicillin- Clavulanic acid. Staphylococcus saprophyticus was $100 \%$ sensitive to Amoxicillin- Clavulanic acid but none were sensitive to first generation Cephalosporins. Enterococcus faecalis and Streptococcus agalactiae was $100 \%$ sensitive to Ampicillin. All the Enterococci were sensitive to Amoxicillin- Clavulanic acid. Streptococcus agalactiae strains were $100 \%$ sensitive to Cephalexin and Clindamycin and $66.67 \%$ sensitive to Amoxicillin Clavulanic acid. As Streptococcus agalactiae strain was Erythromycin sensitive no inducible Clindamycin resistance was tested and Clindamycin was reported as sensitive for intra partum prophylaxis. As the strain was Penicillin, Ampicillin and Cephalexin sensitive, Cefazolin was reported as sensitive for using as an alternative drug for prophylaxis.

\section{Gram negative isolates}

Escherichia coli isolates had more resistance rates than other gram negative isolates. E. coli isolates were $100 \%$ sensitive only to third generation injectable drugs like Cefoperazone- Sulbactum, Piperacillin- Tazobactum, Meropenem and Imipenem. Ampicillin was the least sensitive drug (14.2\%) followed by Cephalexin (42.86\%), Cotrimoxazole (42.86\%), Norfloxacin (42.86\%) and Amoxicillin- Clavulanic acid (42.86\%). Ciprofloxacin was $57.14 \%$ sensitive, Cefotaxime and Nitrofurantoin (both $71.43 \%$ ) and aminoglycosides $(85.71 \%)$. For the two Cefotaxime resistant strains, ESBL production was tested and was found to be negative. Klebsiella species was $100 \%$ sensitive to Aminoglycosides, Cefotaxime, Ciprofloxacin and all the third-generation injectable drugs like Cefoperazone- Sulbactum, PiperacillinTazobactum, Meropenem and Imipenem. Cephalexin, Cotrimoxazole, Norfloxacin and Amoxicillin- Clavulanic acid was $83.33 \%$ sensitive. Nitrofurantoin was the least sensitive drug (50\%). None of Citrobacter koseri strains were sensitive to Cephalexin, Nitrofurantoin and Amoxicillin- Clavulanic acid. It was $100 \%$ sensitive to Aminoglycosides, Third generation Cephalosporins, Cotrimoxazole, Fluoroquinolones and higher generaion injectables.

Only low level of resistance was found against Nitrofurantoin, and this might be due to its narrow range of clinical indications, which results in less usage. Resistance to Ciprofloxacin, Norfloxacin, Ampicillin and Amoxicillin- Clavulanic acid could have been contributed by an increase in prescribing practices of these drugs for uncomplicated UTI and other indications in recent years. These drugs are very common due to low cost and often purchased without prescription in different areas.

According to Chidre Yogiraj Vaijanathrao et al from Hyderabad, highest sensitivity was noted to Ciprofloxacin, Gentamicin, Nitrofurantoin, Ofloxacin and Amikacin. ${ }^{37}$ For Gram positive cocci, highest sensitivity was seen with Amoxyclav, Nitrofurantoin, and increasing resistance pattern were seen with Cephalosporins and Ampicillin. Another study by Roopa et al from Karnataka, all the isolates of asymptomatic bacteriuria were sensitive to Gentamicin and $62.5 \%$ isolates were sensitive to Nitrofurantoin. ${ }^{38}$ Study done by Ayoade et 
alfrom Nigeria, showed that all the isolates were resistant to Amoxycillin, Augumentin and Cotrimoxazole but most of the isolates were assessed to be highly susceptible to Ofloxacin. ${ }^{39}$ Three antibiotics namely Ofloxacin, Gentamicin and Nitrofurantoin were found to be most effective for Gram negative bacteria while Gentamicin, Chloramphenicol and Cotrimoxazole were effective for Gram positive bacteria. A study by Amete Mihret Teshale et al from Ethiopia, Nitrofurantoin, Clindamycin and Ciprofloxacin were the most effective antibiotics for Gram positive isolates with less efficacy of Sulfamethoxazole/Trimethoprim for this bacteria. ${ }^{40}$ Gentamicin, Amoxicillin/Clavulanic acid, Norfloxacin and Ciprofloxacin were the antibiotics of choice for Gram negative isolates.

\section{Complications of asymptomatic bacteriuria of pregnancy detected on follow up}

All of the patients with significant growth were informed about the growth and was advised to take treatment immaediately. All 26 patients took treatment. No complications were detected in $14(53.80 \%)$ of subjects. Recurrent asymptomatic bacteriuria and symptomatic bacteriuria was present in $23.08 \%$ and $19.2 \%$ of subjects respectively. These were detected as the most common complications. Pretem labour was noted in only one subject $(3.84 \%)$. But the patient was having other associated complications towards end of delivery. The decreased rate of complications may be due to prompt treatment under taken by the patient. In a study conducted by Lavanya and Jogalakshmi in Vishakapatnam out of 42 subjects with significant growth, 38 cases (90.46\%) complied with treatment and $4(9.54 \%)$ did not. ${ }^{9}$ Three out of $4(75 \%)$ who did not take treatment delivered prematurely and two (50\%) delivered low birth weight babies.

\section{CONCLUSION}

The percentage of asymptomatic bacteriuria of pregnancy is less towards this part of the country. The probable reason could be the prompt antenatal care and good hygienic living of people. Age, parity, gravidity and period of gestation were not found to be associated with asymptomatic bacteriuria of pregnancy. Gram stain was found to be the best screening test with high sensitivity and specificity. In our set-up urine microscopy is the one that is given importance in antenatal screening. If the wet film is positive, then only a sample is sending for culture. But as wet film examination is not having a good sensitivity and specificity according to this study and many other studies, urine culture should always be done as recommended by standard guidelines ideally between 12-16 weeks of pregnancy to decrease asymptomatic bacteriuria and its morbidity. Gram-negative bacteria were isolated from more than half of the samples. Escherichia coli was the most common organism isolated closely followed by Klebsiella spp. Gram-positive bacteria including Group B Streptococci were also isolated in large numbers. Even though pregnancy is considered as an immunocompromised condition, only one Candida isolate was obtained until this period of gestation. Staphylcoccus aureus strains were $100 \%$ sensitive to Cephalexin and all the Staphylococcus saprophyticus strains were sensitive to AmoxycillinClavulanic acid. All the Streptococci were sensitive to Ampicillin. Escherichia coli, the most common organism isolated, was comparatively resistant to the most common antibiotics used like Ampicillin and Cephalexin. Cefotaxime was found to be the best drug which can be used against gram-negative bacteria. Nitrofurantoin was another oral formulation found to be useful for Escherichia coli. But Nitrofurantoin was not that effective for other gram-negative bacilli. Resistance to Ciprofloxacin, Norfloxacin, Ampicillin, Cephalexin and Amoxicillin- Clavulanic acid could have been contributed by an increase in prescribing practices of these drugs for uncomplicated UTI and other indications in recent years. Complications of asymptomatic bacteriuria like preterm labour and low birth weight were almost not detected in this study. This may be due to the prompt treatment and good antenatal care.

Funding: No funding sources Conflict of interest: None declared

Ethical approval: The study was approved by the Institutional Ethics Committee

\section{REFERENCES}

1. Leslie C, Albert B, Max S. Topley and Wilson's microbiology and microbial infections. $10^{\text {th }}$ ed. London: Edward Arnold. 1998;3.

2. Cunningham FG, Gant NF, Laveno KJ. Renal and urinary tract disorders. Williams Obstetrics. 24thEd. New York: McGraw-Hill Medical Publishing Division; 2014:1052-56.

3. Forbes BA, Sahm DF, Weissfeld AS. Infections of urinary tract. Bailey and Scott's Diagnostic microbiology. $12^{\text {th }}$ ed. Missouri: Mosby Elsevier. 2007:842-54.

4. Mandell GL, Bennett JE, Dolin R. Urinary tract infections. Mandell, Douglas, and Bennett's principles and practice of infectious diseases. $7^{\text {th }}$ ed; 2009:957-976.

5. Anantnarayanan R, Ananthanarayanan PJ, Kapil A. Paniker's text book of microbiology. $9^{\text {th }}$ Ed; 2013:277-280.

6. Imade PE, Izekor PE, Eghafona NO, Enabulele OI, Ophori E. Asymptomatic bacteriuria among pregnant women. N Am J Med Sci. 2010;2(6):263-6.

7. Colgan R, Nicolle LE, Mcglone A, Thomas M. Hooton. Asymptomatic bacteriuria in adults. Am Family Physician. 2006;74(6):985-90.

8. Chandel LR, Kanga A, Thakkur K, Mokta KK, Sood A, Chauhan S. Prevalance of pregnancy associated asymptomatic bacteriuria: a study done in a tertiary care hospital. J Obstet Gynaecol India. 2012;62(5):511-4. 
9. Lavanya SV, Jogalakshmi D. Asymptomatic bacteriuria in antenatal women. Indian $\mathrm{J}$ Med Microbiol. 2002; 20(2):105-6.

10. Jain V, Das V, Agarwal A, Pandey A. Asymptomatic bacteriuria and obstetric outcome following treatment in early versus late pregnancy in north Indian women. Indian J Med Res. 2013;137(4):753-8.

11. Demilie T, Beyene G, Melaku S, Tsegaye W. Urinary bacterial profile and antibiotic susceptibility pattern among pregnant women in north west ethiopia. Ethiop J Health Sci. 2012;22(2):121-8.

12. Hagay Z, Levy R, Miskin A, Milman D, Sharabi H, Insler V. Uriscreen, a rapid enzymatic urine screening test: useful predictor of significant bacteriuria in pregnancy. Obstet Gyaecol. 1996;87:410-3.

13. Simmons NA, Williams JD. Use of a solid reagent in the triphenyl tetrazolium chloride test for bacteriuria. J Clinic Pathol. 1967;20:767-9.

14. Khattak AM, Khan H, Akhtar W, Mahsud I, Ashiq B. Accuracy of Griess test to predict asymptomatic bacteriuria during pregnancy. Gomal J Med Sci. 2004;2(1):20-4.

15. Ansari HQF, Rajkumari A. Prevalence of asymptomatic bacteriuria and associated risk factors among antenatal women attending a tertiary care hospital. J Med Allied Sci. 2011;1(2):74-8.

16. Patil SS, Mahale K, Krishna S, Mariraj J, Kalabhavi AS, Sathyanarayan MS. Evaluation of gram stain of uncentrifuged urine as a screening method for diagnosis of urinary tract infections. Curr Res Medic Med Sci. 2011;1(2):19-21.

17. Clinical and Laboratory Standards Institute. Performance standards for antimicrobial susceptibility testing. Twenty-Fifth Informational Supplement. M100-S25. 2015;35(3).

18. Lee M, Bozzo P, Einarson A, Koren G. Urinary tract infections in pregnancy. Can Fam Physician. 2008;54(6):853-4.

19. Jayalakshmi J, Jayaram VS. Evaluation of various screening tests to detect asymptomatic bacteriuria in pregnant women. Indian Journal of Pathology and Microbiology. 2013;51(3):379-81.

20. Jennifer P, Cyril R, Piyumi P, Nimesha G, Renuka J. Asymptomatic bacteriuria in pregnancy: prevalence, risk factors and causative organisms. Sri Lankan J Infec Diseas. 2012;1(2);42-6.

21. Prasanna B, Naimisha M, Swathi K, Shaik MV. Prevalence of asymptomatic bacteriuria in pregnant women, isolates and their culture sensitivity pattern. Int J Curr Microbiol Applied Sci. 2015;4(8):28-35.

22. Kerure SB, Surpur R, Sagarad SS, Hegadi S. Asymptomatic bacteriuria among pregnant women. Int J Reprod Contracep Obstet Gynecol. 2013;2(2):213-6.

23. Hamdan HZ, Ziad AHM, Ali SK, Adam I. Epidemiology of urinary tract infections and antibiotics sensitivity among pregnant women at
Khartoum North Hospital. Ann Clin Microbiol Antimicrob. 2011;10(2):1-5.

24. Alemu A, Moges F, Shiferaw Y, Tafess K, Kassu A, Anagaw B et al. Bacterial profile and drug susceptibility pattern of urinary tract infection in pregnant women at University of Gondar Teaching Hospital, Northwest Ethiopia. BMC Res Notes. 2012;5:197.

25. Cardoso CL, Muraro CB, Siqueira VL, Guilhermetti M. Simplified technique for detection of significant bacteriuria by microscopic examination of urine. $\mathbf{J}$ Clin Microbiol. 1998;36(3):820-3.

26. Taneja N, Chatterjee SS, Singh M, Sivapriya S, Sharma M, Sharma SK. Validity of quantitative unspun urine microscopy, dipstick test leucocyte esterase and nitrite tests in rapidly diagnosing urinary tract infections. J Assoc Physicians India. 2010;58:485-7.

27. Willy Fred Nabbugodi, J. Wanyoike Gichuhi, and N. W. Mugo. Aetiology and antibiotic sensitivity pattern among antenatal women presenting with lower abdominal pains at Kenyatta National Hospital, Nairobi, Kenya. Open Access J Sci Tech. 2015;3:1-6.

28. Mokube MN, Atashili J, Halle-Ekane GE, Ikomey GM, Ndumbe PM. Bacteriuria amongst Pregnant Women in the Buea Health District, Cameroon: Prevalence, Predictors, Antibiotic Susceptibility Patterns and Diagnosis. PLoS One. 2013;8(8):e71086.

29. Siddiqui SM, Deshmukh AB, Afreen U, Bhanap PL. Evaluation of screening tests to detect asymptomatic bacteriuria in obstretic patients at Noor Hospital, Warudi, Jalna, Maharashtra. MedPulse-Int Med J. 2014;1(10):623-6.

30. Berger SA, Bogokowsky B, Block C. Rapid screening of urine for bacteria and cells by using a catalase reagent. J Clinic Microbiol. 1990;28(5):1066-7.

31. Shilpa K, Bernaitis L, Jiji Mathew, Shobha KL, Ramyasree A, Manthena A. Comparison of urine microscopy and culture from urinary tract infection a retrospective study. International Journal of Health Information and Medical Research. 2015;2(1):12-7.

32. Pezzlo M. Detection of urinary tract infections by rapid methods. Clinic Microbiol Reviews. 1988;1(2):268-80.

33. Gayathree L, Shetty S, Deshpande SR, Venkatesha DT. Screening for asymptomatic bacteriuria in pregnancy: an evaluation of various screening tests at the Hassan District Hospital, India. J Clinic Diagno Res. 2010;(4):2702-6.

34. Mukherjee K, Golia S, Vasudha CL, Babita, Bhattacharjee D, Chakroborti G. A study on asymptomatic bacteriuria in pregnancy: prevalence, etiology and comparison of screening methods. Int $\mathbf{J}$ Res Med Sci. 2014;2(3):1085-91.

35. Udawat M, Nithyalakshmi J, Sumathi G, Mallure S. A study on the prevalence of asymptomatic bacteriuria and their antibiogram pattern among 
pregnant women in a tertiary care hospital. J Evolution Med Dent Sci. 2014;3(28):7920-7.

36. Nithyalakshmi J, Vijayalakshmi. Bacterial profile and antibiogram pattern of UTI in pregnant women at tertiary care teaching hospital. Int $\mathbf{J}$ Pharma and Bio Sci.2014;5(4):201-7.

37. Vaijanathrao CY, Nalini YL, Reddy CM. Antibiotic sensitivity pattern of uropathogens: a comparative study between symptomatic and asymptomaic bacteriuria in pregnant women. Int $\mathbf{J}$ Curr Microbiol Applied Sci. 2015;4(6):689-95.

38. Roopa C, Biradar S. Incidence, microbiological profile and antibiotic susceptibility pattern of symptomatic and asymptomatic bacteriuria in antenatal women. Int $\mathbf{J}$ Curr Microbiol Applied Sci.2015;4(9):962-8.
39. Ayoade F, Moro DD, Ebene OL. Prevalence and antimicrobial susceptibility pattern of asymptomatic urinary tract infections of bacterial and parasitic origins among university students in redemption camp, Ogun State, Nigeria. Open J Med Microbiol. 2013;3:219-26.

40. Teshale AM, Desta K, Mulugeta G, Asamene N, Birara M, Fentaw S et al. Prevalence and antibiotics susceptibility pattern of common bacterial uropathogens isolated from pregnant women attending antenatal care clinic at St. Paul Hospital Millennium Medical College And Selam, Health Center, Addis Ababa. Ethiopia. 2015;2(9):1288-130.

Cite this article as: Bose AM, Sreekumary PK, Pulikkottil SK. Microbiological profile of asymptomatic bacteriuria in pregnancy. Int J Reprod Contracept Obstet Gynecol 2017;6:1352-61. 